\title{
Good Governance in Extremism and Militancy: A Case of Pakistan
}

\author{
Faheem Akhter * $\quad$ Khalid Mehmood Iraqi ${ }^{\dagger}$
}

\begin{abstract}
The importance of good governance for stability and peace in a country cannot be ruled out especially in this era of globalization; good governance has become an important element to achieve prosperity through social and economic stability. Pakistan which is undergoing extremism and militancy for the last couple of years, is also deprived of good governance. Sudden rise in extremism and militancy poses a great danger and a serious threat to the governance of Pakistan. Institutions operating to curb the peril are also directly or indirectly becoming victim of terrorist actions. Pakistani nation feels great pain seeing explosions, killings, violence, violation of law and order and series of street crimes and other violations having no recess in between. An effort is made to carry out qualitative research on the presented theme, in a sequence, at initial level common understanding and prevalence of increase in militancy and violence is discussed; followed by a study on terrorist actions and terrorism is talked about while highlighting the governance's troubles in Pakistan. Data is collected through available literature's review, published official reports from the state's institutions, interviews of selected and targeted people, think tanks, experts in the relevant field and evidence from the society. The aim is to draw logical grounds for the decision makers to identify the areas to be focused on providing a respectable and reasonable life to the common citizens of Pakistan through good governance, economic stability, peace and rule of law.
\end{abstract}

Keywords: Good governance, extremism, militancy

\section{Introduction}

There is a constant war against terrorism in Pakistan for the last few years. Pakistan armed forces backed by the entire nation is engaged in war against terrorists. Pakistan's security challenges have never appeared so prevalent and widespread, as they stand today. The ideology basing on which Pakistan got independence is under threat for the last couple of years, some regional and global powers are striving hard to destabilize "The Fort of Islam". Hence there is a need to identify the ingenious methods to meet the security needs.

Governance is as old as human civilization and Good Governance means the process of decision making and implementation. There is a positive correlation between success and good governance. Pakistan is under threat of social, cultural and psychological warfare which lead the nation towards conflict and intolerance and make the state a badly governed state. Corruption in judiciary, bureaucratic inefficiency, inefficient and corrupt law enforcement agencies, undermine the capacity of institutions to facilitate good governance for sustainable development. Having so many gray areas push Pakistan into the

*PhD Scholar, University of Karachi, Pakistan. E-mail: faheem8687@yahoo.com

${ }^{\dagger}$ Professor, University of Karachi, Pakistan. E-mail: khalid.iraqi@yahoo.com 
line of failure states and also made her vulnerable. In order to counter and have an efficient defense against the stated threats, the research would offer the preventive measures which could be taken by addressing multiple areas of social beautification.

The nature of conflict has always been evolving and the changes have mostly been influenced by the social, political and technological advances. At times diversification of the conflict spectrum has been the outcome of societal development, while on the other occasions it actually sets the pace for societal changers. Yet the primary constituent of an evolving social order has been its ability to harness and absorb the changes.

The prime beneficiary of the good governance in a state is its nation. Those involved in the decision making process are responsible to provide the basic needs of the people. Pakistan now in the eyes of the world has become a troubled state and entire global community is focusing to correct Pakistan's governance. The research is an endeavor to critically analyze the prevailing causes and effects of extremism and militancy in the society. Terrorists acts, violation of law and order increasing militancy are pushing the state towards bad governance. While there is a profound and an inescapable impact of changing geopolitical scenario on Pakistan her inner front which has already been left feeble due to years of mismanagement and bad governance appears too fragile to withstand any further stress.

The research is significant for the students of Social and Management Sciences to carry out research to find out and highlight social ills. It also provides a social service to the nation, works as a reference for future study on the subject to identify the weak societal links. The country in general and particularly the religious and political extremists may also get help to rectify the faults in system. Policy makers may also see this to identify the weak areas of governance.

\section{Literature Review}

Constitution of Pakistan demands respect to the law and abiding the rules and regulations for becoming a progressive country and civilized nation. In his book "In the Arena" (Nixon, 2000) the former US president writes, ".. to break away from the decadent traditions of the colonial past and promote professionalism and nationalism but must also be seen as such by our compatriots, for perceptions are quite often stronger than the reality". Setting goal, giving task to the concerns and monitoring and evaluation of the result would contribute in achieving good governance in every sphere especially in public sector in Pakistan, the key point has been highlighted in his book "Good Governance and Result Based Monitoring", by (Khawaja, 2011). Pakistan is targeted by the external extremists through their internal players they are trying hard to destabilize Pakistan (Akhter, 2016b). The making of long term planning and setting the direction to execute is the objective; "Principle centered leadership", (Covey, 1992) is a well written book by Stepen R. Covey, in making sense in problem solving at any level especially national level, which ultimately results into good governance. A well thought out and effectively executed public policy would result into good governance. "Public Policy: Formulation Implementation Analyses: Pakistan Focused", (Khawaja, 2013) a book written by Dr. Sarfraz Khawaja 
gives a clear path to the government to formulate and implement the policy. However, with increase in TV channels there is a competition amongst the opinion builders, resultantly the opinion does not go for a long time and people weigh their own thought. Tottier (2006) in their research article "Information Warriors: Battling for data dominance in the fifth Dimension", talk about the same phenomena. Qadeer (2006) in his book "Pakistan Social and Cultural Transformation in a Muslim Nation", discusses the issue of sectarianism and militancy in Pakistan. Pakistani nation has a positive strength like adherence to the teachings of Islam, this issue is being exploited by the rivals and they made it weakness by using negative propaganda tools (print and electronic media, human resource). In order to reduce the ongoing conflict and terrorism in Pakistani society Faheem Akhter in his research Education, Dialogue and Deterrence: Tools to Counter Terrorism (Akhter, 2016a), suggests that the people must give education to differentiate the terrorist and the heroes. More over dialogue to discuss the issues and to find out the ways to overcome the problems and finally the punishment to the wrong doers to create deterrence for the potential wrong doers will help countering terrorism.

Leadership is the most important factor in success of a nation. "The Military 100-A Ranking of the Most Influential Military Leader of All Times" (Lanning, 1996), is a book which gives a list of hundred leaders of all times, though the author Lieutenant Colonel Michael Lanning (Retired), has covered the martial trait of the leaders but it also describes the way these leaders successfully organized and established the governance, thus it also encourages me to research deeply on the subject. The psychology of a nation is reflected in its army too, thus it also helps in determining how the army may behave while dealing with the adversary. Robert and William (1984) in their book "Military Leadership in Pursuit of Excellence", combine the classic and contemporary articles, and innovative essays, on leaders, followers, and the personal and organizational values that promote effective military leadership. since war against terrorism is fought by the civil and military leadership on their respective fronts the book remained source of information and encouragement for my research. Thomas (2009) is the Washington Post's senior Pentagon correspondent, and had been the reporter of The Wall Street Journal for seventeen years, he has also lived in Afghanistan and Hong Kong. "Fiasco: The American Military Adventure in Iraq", is an interesting book which gives a true picture of the on ground reality, provides eye-witness explanations that challenge the official stories and figures. The book also gives a scary depiction of the deceitfulness, wishful thinking, lack of vision and intellectual failure of think-tanks. It clearly shows the actual cause of the fighting in Iraq, the physical and psychological damages accrued. The governance crisis in Pakistan is not new however same is being talked about by S. Mahmood (2007) in his book "Good governance reforms agenda in Pakistan: current challenges". These challenges emerged as a result of Global War on Terrorism. "Governing the Market: Economic theory and the Role of Government in East Asian Industrialization", (Wade, 1990) a book written by Robert Wade describes the standard in contemporary political economy. Wade in his book presents counter argument to the claims of those who think the East Asian story is an exception of free market principles and of those who attributed the success of Taiwan and other countries. Wade turned the attention towards the allocation decisions which were divided between markets and public administration and the synergy between these two. 
In addition, he also reviews the dispute about industrial policy in East and Southeast Asia and accounts the changing prosperities of these economies in 1990s and emphasizes the importance of good governance as it is must for prosperity of any country. Print and electronic media has very strong influence on public opinion, media very successfully control and mold the opinion by showing biased and one sided story (Akhter, 2016b). Massive urbanization has resulted into demographic and social change. It has increased chaos and badly affected the civic sense and social behaviors.

\section{Research Design}

It is a qualitative research based on observational analytical and focus group discussion, through random and purposive sampling. The views of field military generals, troops and levies (local police force) operating against terrorists and militants; think tanks and local inhabitants were taken into account. The study is designed to collect data by semistructured interview of those people who are office bearer and advisors to policy makers they are government officials, head of the institutions (National institute of Public Policy or National Institute of management etc. and high officials in Armed forces of Pakistan). The purpose of collecting data is to get the close and true picture of increasing militancy and decline in governance in Pakistan.

\section{Data Collection and Analysis}

Data is collected using all available print and electronic authenticated resources, view of the target folks and published official reports (available on official website) whereas for the authentication and accuracy data analysis is done through content analysis. The impact of increasing militancy on absence of good governance in Pakistan is analyzed through this research. A deep study and analysis of literature on the subject reveal that the ongoing wave of extremism, militancy and terrorism in Pakistan is pushing Pakistan into a troubled state. The prevailing forms of extremism and the acts of terrorism have impact on Pakistan's governance.

\section{Prevailing forms of Extremism in Pakistan}

\section{Confrontation of Ideology}

Pakistan is God's precious gift and not only a country on world's map this is what common people believe. The first country on face of the earth which was created to practice the ideology of Islam. Muslim population of the sub-continent strived hard and after long painful journey got independence to practice their religion in true letter and spirit (M. G. Mahmood, 2008). The religion Islam presents the complete code of life and guides in all walks of life that may be individual, social, fiscal, political, justice, martial, etc. Worth mentioning that Pakistan was created for better living of not only Muslims but also all citizens irrespective of their religion, cast or creed. Better living cannot be obtained without strong economy, political stability, secure environment, literacy and peace 
of mind.

\section{Cause Effect Relation of Islam and Terrorism}

Mostly talked phenomenon in today's lexicon, which has direct relevance to Pakistan and her security dynamics is Islam and terrorism. Post 9/11, great pain is taken to establish a cause-effect relationship between Islam and terrorism. Concept of Jihad gets portrayed as philosophy of terrorism and Muslims in general and viewed with suspicion, while practicing Muslims are portrayed as extremists. Eventually or unfortunately most of the troubled zone on the globe are mapped to Muslim world and the conflict are attributed to an ideological appeal with spiritual motivation and intellectual justification coming from Islam (Liotta, 2011). It is in this context that Muslims world over are being marginalized as a threat and even the legitimate freedom struggles such as Palestine and Kashmir are dubbed as terrorism. Terrorism is being portrayed as a genetic problem and not a social or political.

\section{Politicizing the Religion of Peace}

While "Radical Islamist" are taken as a threat perpetrating extremism and terrorism to fulfill their perceived objectives, western think tanks openly target "Political Islam" as a continuous threat. Islam is not just a religion, rather it is a complete code of life, which provides all-encompassing social, political, economic order and harnesses fundamental aspects of an individual, society and state (Hilali, 2004). Any such system is believed to be based upon the literal and conservative reading of the Quran and Hadith, offering an alternative to the present social and political framework. A further distinction is made whereby the conservative stream of Muslims is divided into two peaceful and violent. While the former is assumed to be embracing modernity, the later are perceived to be rejecting it. It is this second form which is termed as Jihadi and signifies terrorism and practicing of Islam. Interestingly while moderation in the Muslims is encouraged in the media, the term implies westernizing and the contention to let people live as they choose; implies western way, as any other way is not considered to be enlightened (Armstrong, 2000).

\section{Social and Economic Vulnerability}

In the global context, proponents of irregular warfare, may they be called extremists, terrorists or fundamentalist; cannot be eliminated through local action against their pockets; instead the requirement is to address the root cause, which lies unresolved that gives rise to such tendencies. The outright motivators of extremists are the 'ideas' and 'belief' responsible of extremist activities (Pakistan Army, 2012a). Therefore, if motivation of extremists has to be tampered with it will only possible through a protracted campaign aimed at winning back the populace i.e. hearts and minds of the people which is possible through political, social and economic emancipation. 


\section{Ethnic Conflicts}

The Pakistan movement surpassed ethnic, linguistic, cultural and regional differences and merged into a powerful struggle culminating in the creation of an independent homeland. The ethnic issue is so strongly embedded in our politics, that virtually it has engulfed all the provisions with varying intensity. Ethnic differences appear to be the most recent threat to the already destabilized internal security situation of the country. Due to one reason or the other, most of the ethnic groups who did not demand a separate identity before have surfaced in the past couple of decades. There is no denying the fact that Pakistan has been home to many ethnic communities since its inception, but they did exist peacefully (Gordon, 2005).

\section{Good Governance: A Neglected Aspect in Pakistan}

Success of a country and good governance has a strong connection. The effect of globalization on good governance cannot be ruled out in current scenario. Due to the continuous terrorist's act and extremism, Pakistan is showing picture of a failure state in the eyes of the world.

\section{Essentials of Good Governance}

Good governance rests on the following essentials:

\section{Constitutional Supremacy}

Principles, rules, regulations and law are made to maintain peace and stability in society (Rodrik, Subramanian, \& Trebbi, 2004). The state must have a restraining infrastructure over the real utilization of power in the public arena and ensure the requirement of its laws. The state should likewise offer a political procedure that ensures the interest of all individuals.

\section{Edification}

The state has the responsibility to make optimal use of the intellectual resources of its society. This includes giving all children access to affordable education according to their abilities and protecting them from exploitation for short term gains, thereby securing a society's longer term investment in adequate education.

\section{Political Stability}

Globalization has made the world a village where all the states are interdependent and without interdependency no prosperity can be achieved. Political stability is the most important factor for consistent national policy. Not the individuals but the policy should be strong. 


\section{Securing Fair Competition}

In order to make the people satisfied there is a need to have fair competition in all the walk of life. Whether admission in schools, colleges and universities; selection for a state driven job or tender to accomplish job merit should be adhered to setting aside nepotism and favouritism. Fair chance be given to the people so that no one should point figures on the selection criteria.

\section{Essentials of Good Governance and Pakistan's Suffering}

\section{Feeble Governance's Institutions}

The main institutions of governance consist of legislature that prescribes laws and the regulatory framework; judiciary needed to protect life, property and rights and enforce contracts; and the administrative bodies that make policies and supplies public goods and services. If the access to the institutions of governance for common citizens is difficult, time consuming and costly the benefits from growth get distributed unevenly as only those who enjoy preferential access to these institutions are the gainers.

\section{Feeble Writ of the Government}

In absence of transparency and accountability the ruling elites use public offices for their personal and familial enrichment by appointing their cronies and confidants to key departments. The main preoccupation of these appointees is to divert the resources away from the general public to themselves, their cronies and their benefactors. Thus writ of the government is challenged on road, markets, showing arrogance, protest intolerance and criminal activities.

\section{Absence of Transparency and Accountability}

Transparency and accountability mechanisms become weak over time. Excess of discretionary powers, violation of the established rules and diversion of public resources for private profits became the norms of behavior. The accountability mechanisms were used selectively to win over the opponents of the ruling parties. The use of accountability for political maneuvering has brought it to such disrepute in the public that even genuine attempts to bring the corrupt to the books have met with skepticism, scorn and ridicule.

\section{Absence of Independent Judiciary}

The courts were congested with backlog of cases going back to several decades and the police investigation, prosecution were flawed in most cases (Indian Development, 2012). The legislatures were suspended several times before completing their due tenure and their members indulged most of the time in maximizing privileges for themselves and loved ones. Laws aimed at helping the poor were hardly enacted. 


\section{Rule of Business Law}

The institutional infrastructure instead of becoming stronger and responsive over time outlived its usefulness due to the weak implementation of rule of law (Myrdal, 1968). Human resource intake and career progression depended not on competence and performance but upon keeping the political bosses pleased, pay and compensation packages were out of sync with the rising cost of living, business processes were outdated, performance appraisal was perfunctory and use of modern technology neglected (Pakistan Army, 2012b).

\section{Impact of Extremism on Governance}

\section{Economic Cost of Terrorism}

Not wrong to say that terrorism has done immense damage to the economy which is struggling to recover from a deep crisis. According to a survey terrorism has cost the economy a hefty sum of Rs. 380 billion in 2008 alone (Jamal, 2009). Over all terrorism has cost the country's economy more than $\$ 35$ billion in exports lost, revenues, opportunity etc. It has been seen that due to these terrorist activities in the country, the image of the country has been badly affected. As a result of this Pakistan has lost her repute in the world's community as many states are now hesitant to issue visas to Pakistani national students, professionals and businessman.

\section{Damaged Tourism}

Increased security concerns have made foreign investors to be less willing to travel to Pakistan to make business deals, consequently most of the country's hotels are running short of business, which has a negative effect on the economy. Along with this tourism of the country has been seriously affected as according to estimates only less than $1 \%$ of people want to visit Pakistan for vacation purpose which is only because of the security threat. This has reduced any chance of foreign income which can be earned through tourism sector.

\section{Social Disharmony}

Because of the prevailing law and order situation the society is divided into different school of thoughts. A section supports religious extremists due to their connections with the religion where as another think such activists are using the religion for their own interests. Rallies, road blocks, shutter-downs in the name of religious gathering and protests put government into trouble. To counter such activities government has to divert the resources. 


\section{Law and Order}

The most challenging part now a day for the government is to maintain law and order situation. Government is pulling Rangers from the borders to the urban areas in aid of civil power. This though helps in maintaining the law and order in the urban areas however putting pressure on the forces deployed to guard the frontiers.

\section{Conclusion}

Pakistan, in the expanded security environment is facing complex security scenario unprecedented in history. An effort has been made to identify the multidimensional security threats emanating from various centers of power in the changed global / regional environment, their interplay with the domestic sensitivities and the options available with Pakistan to respond to these threats. Malala Yousufzai is second Nobel Lauriat of Pakistan who raised voice against the victimization and terrorist acts in areas adjacent to Afghanistan. She drew the attention of entire world towards this menace. Armed forces operation in Federal Administrative Tribal Areas (FATA) and Khyber Pakhtoon Khaw (KPK) province is evident that militants were operating from those areas. Number of militants were killed or apprehended by law enforcing agencies in FATA and KPK. Pakistan has great potentials to address its vulnerabilities, however, there is a need to remain forewarned, in line with the famous dictum 'Forewarned is being Forearmed', and evolve well considered, pragmatic, consonant with the emerging realities and challenges. (M. G. Mahmood, 2008). Internal disharmony, political, ethnic, and sectarian division has made increased her vulnerabilities and given a fair chance to the regional and extra regional powers to weaken her by imposing their narratives. In addition to these divisions few other vulnerable areas of Pakistani society are unequal distribution of wealth, low literacy rate, lack of national cohesiveness, nationalism, widespread corruption at all levels, mindset to violation of rule of law. Lives, properties, and culture has suffered damages by the terrorists in different forms and shapes. There is a need to adopt strategy of Education, Dialogue and Deterrence to defuse the density of terrorism and to counter the menace of terrorism (Akhter, 2016a).

\section{Recommendations}

There is a need for creation of a stable domestic environment through good governance and economic development in countering this menace regardless of so called political fallout government has an obligation to show firmness resolve and take decisive action against known enemy by administering deterrent punishment (Hilali, 2004).

Provision of equal and equitable opportunity to every citizen, ensure abiding law, and justice in every walk of life will have more satisfied population working for the prosperity of state. Pakistani society has suffered a lot due to terrorist's activities all over the country. Not getting fair chance to progress makes a young boy and girl frustrated who sometimes fall into the hands of anti-state elements then they use them for their motive. 
A prosper, flourishing and strong Pakistan is the need of not only people and government of Pakistan but also surrounding countries and rest of the world. Economic activities and betterment in life style can be brought by a mix of national integration, pride, hard work and sincere leadership. Extremism is an exceptional barricade in Pakistan's Political, Social and Economic affluence, political stability, geo-strategic sustainability and energy sanctuary. The positive note of the entire research is that irrespective of all ills and declines that Pakistan is undergoing, bright future is waiting with opened arms.

Pakistan and China are allies since inception. China has also gone through these turmoils however, China has been able to overcome by adopting economic and foreign policy reforms (Hashmi, Khan, \& Khan, 2014). Pakistan can also adopt the same model. 


\section{References}

Akhter, F. (2016a). Education, dialogue and deterrence: Tools to counter terrorism. Sociology and Anthropology, 4(4), 257-262. Retrieved from https://doi.org/ $10.13189 \% 2 \mathrm{Fsa} .2016 .040408$

Akhter, F. (2016b). Extremism in Pakistan: Need to refreshing the garden through reformation. International Journal of Research in Social Sciences, 6(6), 229-241.

Armstrong, K. (2000). The battle for God: A history of Fundamentalism. New York: Ballantine Publishing Group.

Covey, S. R. (1992). Principle centered leadership. London, West Garden Palace, Kendel Street: Simon and Schuster Ltd.

Gordon, S. (2005). Rise to power in the twentieth century and beyound. London: St Martin press.

Hashmi, S. R., Khan, M. A., \& Khan, M. M. (2014). China's foreign policy choices and domestic constrains: Maneuvering for peaceful rise. Journal of Education $\mathcal{E}$ Social Sciences, 2(2), 163-172.

Hilali, A. (2004). Geo strategic importance of Pakistan. Pakistan Defence Review, 20-23.

Indian Development. (2012). Changing global security environmnent. Retrieved from adb . org: http: / / www.adb.org/media/articles/2012/12435

Jamal, N. (2009). Economic cost of terrorism. Islamabad: Daily Dawn.

Khawaja, S. (2011). Good governance and result based monitoring. Islamabad: Poorab Academy.

Khawaja, S. (2013). Public policy: Formulation implementation analyses: Pakistan Focused. Mr. Books, Super Market, Islamabad, Pakistan.

Lanning, M. L. (1996). The military 100: A ranking of the most influential military leaders of all time. Secaucus. NJ: Citadel Press/Carol Publishing Group.

Liotta, P. H. (2011). Chaos as strategy. Parameters, 41(4), 1-10.

Mahmood, M. G. (2008). Future conflict environment challenges and response. Pakistan Army Green Book.

Mahmood, S. (2007). Good governance reform agenda in Pakistan : Current challenges. New York: Nova Science Publishers.

Myrdal, G. (1968). Asian drama, an inquiry into the poverty of nations. New York: Pantheon.

Nixon, R. (2000). Seize the moment. New York: Simon and Schuster.

Pakistan Army. (2012a). Changing global security environmnent. Retrieved from Pakarmy: http://www.idsi.org/globalsecurityenvironment

Pakistan Army. (2012b). Retrieved from http: / / www • pakistanarmy • org • pk

Qadeer, M. (2006). Pakistan-social and cultural transformations in a Muslim Nation. New York: Routledge.

Robert, L. T., \& William, E. R. (1984). Military leadership in pursuit of excellence. USA: Westview Press.

Rodrik, D., Subramanian, A., \& Trebbi, F. (2004). Institutions rule: The primacy of institutions over geography and integration in economic development. Journal of Economic Growth, 9(2), 131-165. 
Thomas, E. R. (2009). Fiasco: The American military adventure in Iraq. Lahore: Izharsons Printers.

Tottier, A. a. (2006). Informations warriors: Battling for data dominance in the fifth dimension. Airman Magazine.

Wade, R. (1990). Governing the market: Economic theory and the role of government in East Asian Industrialization. Princeton University Press. 